\title{
ASSESSMENT OF SOLAR RADIATION IN THE REGION OF LAKE MIEDWIE FOR RECREATIONAL PURPOSES
}

\author{
Department of Tourism, University of Szczecin, Szczecin, Poland \\ 1Department of Meteorology and Landscape Architecture, West Pomeranian University of Technology, \\ Szczecin, Poland
}

\begin{abstract}
The aim of the paper is the assessment of the amount and variability of sums of global solar radiation, diffuse radiation and direct radiation in the area of Lake Miedwie and the resulting conditions for recreation. For this purpose, the study was based on hourly and 24-hour period measurements of the aforementioned types of radiation obtained from the Agrometeorological Station in Lipnik in the vicinity of Stargard in the period 2008-2017 - the measurements were taken using Delta T BF3 Sunshine Sensors. The temporal distribution of global, diffuse and direct radiation was determined according to hours, days, months, seasons and years with average and extreme values as well as coefficient of variation (W\%). The percentage share of sums of diffuse and direct radiation in global solar radiation was calculated and, on the basis of skin erythema dose (SED), safe tanning time for people with blond, chestnut and dark hair was identified for a given day during the warm half-year in the region of Lake Miedwie. There is a high temporal variability and uneven distribution of the types of radiation observed from month to month as well as from year to year. Moreover, the predominance of direct radiation in spring, as compared with autumn, is more than two-fold and more than 18 times greater in summer than in winter. The course of annual radiation is characterised by the occurrence of severaldays-long periods of increased or reduced radiation sum. From the last days of March to the first decade of August, mean daily global solar radiation sums is above $4000 \mathrm{~W} \cdot \mathrm{m}^{-2}$, and from mid-April to the first days of August it exceeds $5000 \mathrm{~W} \cdot \mathrm{m}^{-2}$. From May to August the intensity of direct solar radiation around the noon on sunny days can be onerous and, with increasing sunbathing time, even hazardous to health.
\end{abstract}

Key words: solar radiation, types, amount, variability, temporal distribution, conditions for recreation.

\section{INTRODUCTION}

Due to its favourable location, good quality of water, favourable bioclimatic conditions and accessibility Lake Miedwie is an important regional recreation area, particularly for the residents of Stargard, Szczecin and Pyrzyce. According to the Voivodeship Statistical Office (2013-2015), several thousand tourists visit Lake Miedwie annually - mainly in the period from May to September. The shallow water at the northern shore of the lake and significant actual sunshine duration in summer (June - August), on average 640 hours, result in water temperature values of more than $18^{\circ}$, at times $>25^{\circ} \mathrm{C}$, which promotes swimming and water sports activities. The attractiveness of the reservoir is reinforced by numerous natural features and cultural values in the close vicinity of the lake - accessible through hiking and cycling tours organised by e.g. Stargard Cycling Association (Borówka 2007).

Corresponding author: Bożena Michalska, Department of Meteorology and Landscape Architecture, West Pomeranian University of Technology, Szczecin, Papieża Pawła VI 3A, 71-459 Szczecin, Poland, e-mail: Bozena.Michalska@zut.edu.pl 
Lake Miedwie is the second largest lake in Zachodniopomorskie Voivodeship and fifth in Poland. It is surrounded by a wide stripe of meadows - often alluvial in the south-west part of the area. As a result, in comparison with the adjacent area, Lake Miedwie and the meadows surrounding it can be considered a particular "oasis" with humid and warm air, low precipitation sums and high insolation. In the warm half-year (April - September), mean daily actual sunshine duration amounts to 6.0 hours, and in summer (June - August) from 6.8 to 7.0 hours (Koźmiński et al.). Favourable bioclimatic conditions constitute a significant value of Lake Miedwie in terms of recreational purposes - relatively high solar radiation, high air and water temperature, air humidity as well as certain weather stabilisation observed in summer (Koźmiński and Michalska 2000; Koźmiński et al. 2007, 2012).

Solar radiation initiates numerous physical, chemical and biological processes on the surface of Earth as well as in the atmosphere, only to be returned to the outer space in a changed form. As a result of this, balance is maintained in the energy flow and matter circulation in the Earth-atmosphere system (Kędziora 1999). The amount of net solar radiation on a given area in a 24-hour period and per year is mainly determined by the area's latitude, season and time of day, albedo, atmospheric pollution, type of surface and its relief in geographical landscape (Bogucki 1999; Bryś 2013).

Three IMGW stations located in Kołobrzeg, Gdynia and Gorzów WIkp. which measure solar radiation are situated on the borders of Pomeranian Lake District. Consequently, the measurements of this meteorological element obtained from Agrometeorological Station in Lipnik in the vicinity of Stargard supplement the measurements and can be used for the purpose of assessing solar radiation in Szczecin Lowland, including the nearby Lake Districts (Koźmiński and Michalska 2000, 2005).

The relationship between solar radiation and human health and wellbeing has been established long time ago. The climatic conditions in Poland are characterised by a large deficit of actual sunshine duration in winter and at times excessive sunshine duration in summer and, according to a Japanese biologist Fukui "we live consuming the sun" (Crove 1987).

Our wellbeing is also dependent on the structure of heat balance on a given area - leisure time destination. Out of the several constituent elements of heat balance of the effective area, the most energy is used in the warm half-year for areal evapotranspiration - e.g. for water in the selected ecosystems in Polish province Wielkopolska in July, at mean net radiation $157 \mathrm{~W} \cdot \mathrm{m}^{-2}$, evapotranspiration amounts to $103 \mathrm{~W} \cdot \mathrm{m}^{-2}$ (i.e. $66 \%$ ), warming of air $38 \mathrm{~W} \cdot \mathrm{m}^{-2}(24 \%)$ and water $16 \mathrm{~W} \cdot \mathrm{m}^{-2}(10 \%)$; in a forest at net radiation $135 \mathrm{~W} \cdot \mathrm{m}^{-2}$ respectively: $115 \mathrm{~W} \cdot \mathrm{m}^{-2}(85 \%), 17 \mathrm{~W} \cdot \mathrm{m}^{-2}(13 \%)$ and $3 \mathrm{~W} \cdot \mathrm{m}^{-2}(2 \%)$; fallow land at net radiation $126 \mathrm{~W} \cdot \mathrm{m}^{-2}-62 \mathrm{~W} \cdot \mathrm{m}^{-2}(49 \%), 58 \mathrm{~W} \cdot \mathrm{m}^{-2}(46 \%)$ and $6 \mathrm{~W} \cdot \mathrm{m}^{-2}(5 \%)$ respectively. Consequently, in summer over water reservoirs and in forests the temperature is markedly lower in comparison with the areas devoid of vegetation, particularly as compared with urban centres where evapotranspiration amounts to $47 \%$ of net radiation, warming of air consumes $36 \%$ of energy and warming of surface as much as $17 \%$ (Kędziora 1999).

The aim of the present paper was the assessment of the amount and variability of sums of global solar radiation, diffuse radiation and direct radiation in the area of Lake Miedwie and the resulting conditions for recreation. 


\section{MATERIAL AND METHODS}

The study is based on hourly and 24-hour period measurements of global solar, diffuse and direct radiation obtained from Agrometeorological Station in Lipnik, in the vicinity of Stargard, for the years 2008-2017. The station is located approximately $2 \mathrm{~km}$ to the east of the lake and due to its location is provides a good representation of radiation conditions of the said water reservoir. Due to a small number of meteorological stations conducting measurements of solar radiation (Kołobrzeg, Gdynia, Gorzów Wlkp.), data obtained from the meteorological station in Lipnik complement the network and may be used for the assessment of solar radiation in Szczecin Lowland and nearby lake areas (Koźmiński and Michalska 2000, 2005).

The measurements were taken with the use of Delta T BF3 Sunshine Sensors. In several cases, the measurements of the meteorological element were interrupted because of strong winds, therefore the established equations of linear regression, which showed highly significant relationships $\left(R^{2}>95 \%\right)$ between the monthly sums of global and direct radiation and the monthly sums of actual sunshine duration, were used to calculate the missing amounts of radiation for a given month.

In the course of the study, the following were determined: temporal distribution of global, diffuse and direct radiation per hours, days, months, seasons and years including the average and extreme values, and the coefficient of variation (W\%). The percentage share of sums of diffuse and direct radiation in global solar radiation was calculated. Additionally, for the selected day (24.06.2008), safe tanning time was identified for people with blond, chestnut and brunette hair involved in recreational activities in the region of Lake Miedwie during the warm half-year on the basis of skin erythema dose (SED), as developed by $\mathrm{S}$. Tyczka (1975).

where:

$$
S E D=\frac{A E D}{0.001433 \cdot K_{\mathrm{dir}}}
$$

SED - Skin Erythema Dose (min),

$A E D$ - average erythema dose (blond hair - $36 \mathrm{~min}$, chestnut hair - $40 \mathrm{~min}$, dark hair - $43 \mathrm{~min}$ ),

$K_{\text {dir }}-$ direct solar radiation $\left(\mathrm{W} \cdot \mathrm{m}^{-2}\right)$.

\section{RESULTS AND DISCUSSION}

In the area of Lake Miedwie, the highest global radiation in a year is recorded in June - on average 159597 , and in July $-158510 \mathrm{~W} \cdot \mathrm{m}^{-2}$, followed by May $-152000 \mathrm{~W} \cdot \mathrm{m}^{-2}$, i.e. the months of the highest sun angle and relatively small cloud cover (Table 1). Markedly low global radiation values are recorded in December 13020 and January $-18415 \mathrm{~W} \cdot \mathrm{m}^{-2}$, where the low position of the sun over the horizon coincides with greater cloud cover (Koźmiński and Michalska 2004; Matuszko 2009). Annually, the greatest increase in the sum of global solar radiation is noted between March and April, whereas between September and October the increase is smaller. The sums of the said radiation are found to be 12 times higher in June than in December, which results in the winter month being very onerous in 
terms of health and hygiene-related issues (Bogucki 1999; Kozłowska-Szczęsna et al. 2004). In the area of Lake Miedwie, high variability in the sums of global solar radiation is observed not only from one month to another but also on a year to year basis, which is confirmed by the calculated values of the coefficient of variation (W\%) - the highest values are recorded in November $(21.5 \%)$, followed by January $(16.3 \%)$ Table1. A significantly smaller variability is observed in the monthly sums of the said radiation in August $-8.5 \%$, June and September $9.6 \%$. As is presented in Fig. 1, in the warm half-year of the analysed period the difference between the highest and the lowest monthly sums of global solar radiation is high, for example in May it ranges from 102565 to $195760 \mathrm{~W} \cdot \mathrm{m}^{-2}$ and decreases to a range of a few to several thousand in the winter period (December - February). The monthly course of the sums of global solar radiation over subsequent years is presented in Fig. 2. In 2010 the sums of radiation exceeded $150000 \mathrm{~W} \cdot \mathrm{m}^{-2}$ only in May and June. However, in the preceding year 2009, over the period of 5 months (April - August) the recorded values were approximately $150000 \mathrm{~W} \cdot \mathrm{m}^{-2}$.

Table 1. Average (a), minimum (b) and maximum (c) monthly sums $\left(\mathrm{W} \cdot \mathrm{m}^{-2}\right)$ of global solar radiation and monthly values of coefficient of variation (W\%) in Agrometeorological Station in Lipnik. Period 2008-2017

\begin{tabular}{|c|c|c|c|c|c|c|c|c|c|c|c|c|}
\hline & 1 & II & III & IV & V & $\mathrm{VI}$ & VII & VIII & IX & $x$ & XI & XII \\
\hline a & 18415 & 34008 & 72236 & 116756 & 152000 & 159597 & 158510 & 130896 & 91732 & 48915 & 20086 & 13020 \\
\hline b & 14774 & 26644 & 60791 & 94931 & 102565 & 136927 & 133088 & 3113810 & 76296 & 32301 & 13056 & 10923 \\
\hline c & 24459 & 40961 & 92031 & 155779 & 195760 & 181168 & 182274 & 149366 & 106078 & 56983 & 30227 & 14909 \\
\hline W \% & 16.3 & 13.6 & 13.3 & 13.7 & 15.9 & 9.6 & 11.0 & 8.5 & 9.6 & 15.0 & 21.5 & 12.1 \\
\hline
\end{tabular}

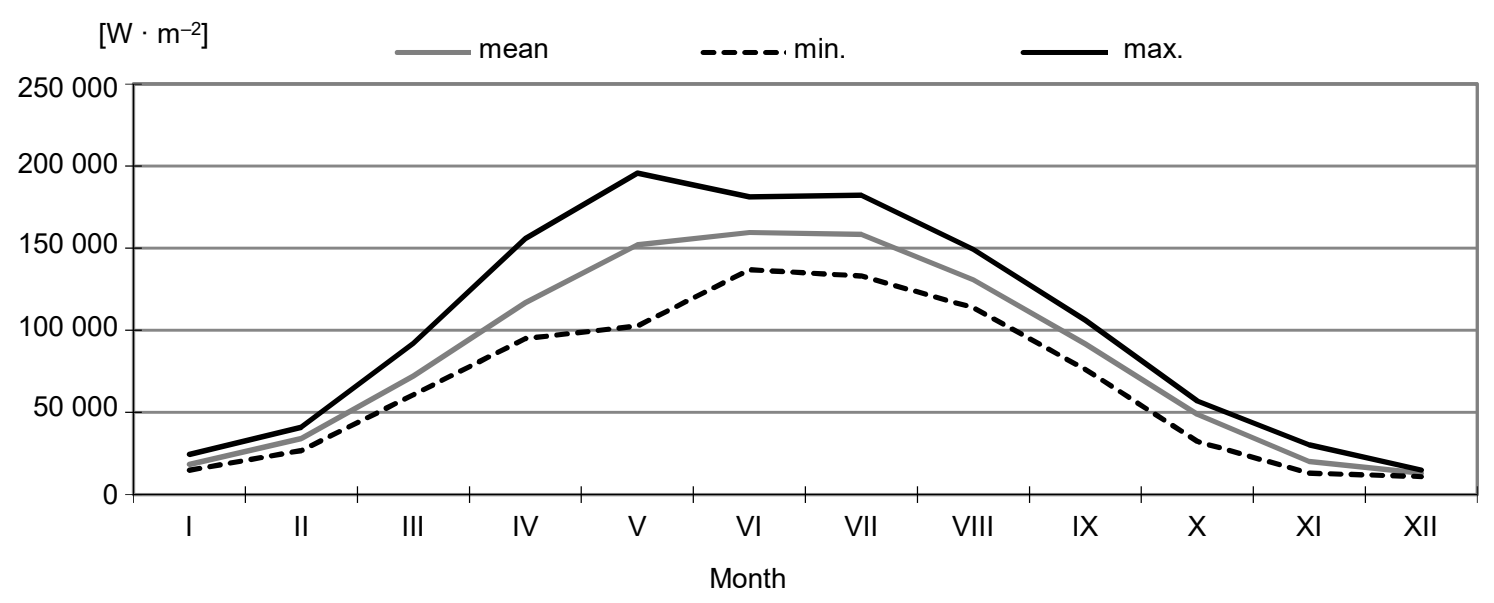

Fig. 1. The course of average, minimum and maximum monthly sums of global solar radiation in Agrometeorological Station in Lipnik. Period 2008-2017 


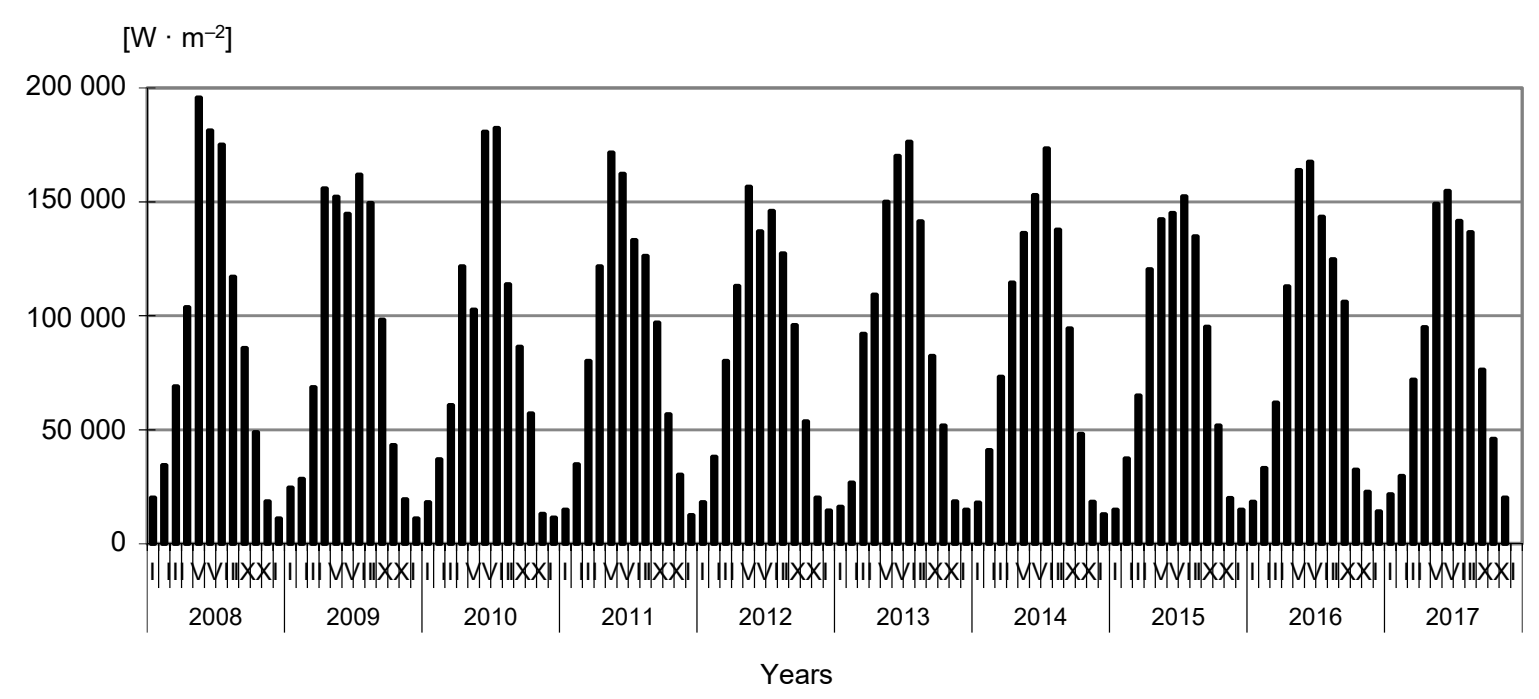

Fig. 2. Monthly course of the sums of global solar radiation in subsequent years of the period 2008-2017 in Agrometeorological Station in Lipnik

Apart from the sums of global solar radiation, other factors are also important regarding the recreational values of a given area such as the sum of diffuse and direct radiation, particularly in winter where there is a significant lack of actual sunshine duration. For example, average actual sunshine duration in the region of Lake Miedwie in December amounts to merely 1.0 hour, in November 1.2 and in January 1.4 hour (Koźmiński et al. 2012).

As is presented in Table 2 and Fig. 3, the percentage share of the sums of diffuse radiation in a year ranges from $2.3 \%$ in December to $13.7 \%$ in June and July, and little less in May $-13.5 \%$ of the annual sum. A markedly greater percentage variation from one month to another is found for the sums of direct radiation - from $0.2 \%$ in December to $17.9 \%$ in June and $17.6 \%$ in July. The greatest increase in the monthly sums of direct radiation occurs between March and April, whereas the decline is observed between September and October. Out of the four analysed seasons of a year, the summer (June - August) is characterised by almost two times greater amount of direct radiation in comparison with winter (December February), and spring (March - May) is marked by double amount of the radiation recorded in autumn (September - November). This means that solar radiation in the summer period is more favourable for recreational purposes as autumn is often very cloudy. In spring, relatively sunny April and May are found to be the favourable months. Due to small sums of direct radiation in winter, one should take advantage of even the shortest, several minutes longs actual sunshine duration - particularly on days with snow cover, albedo of which can amount to $40-60 \%$ and even more on out-of-town areas (Kędziora 1999). In the warm halfyear, monthly direct radiation varied in particular years. The highest variations were recorded in May, i.e. from 37947 in 2010 to $123272 \mathrm{~W} \cdot \mathrm{m}^{-2}$ in 2008, as compared with diffuse radiation which shows greater stability and less variations (Fig. 3 ).

Table 3 presents the share of annual diffuse radiation in the sum of global solar radiation which amounts to $51.5 \%$, as well as the sum of direct radiation $-48.5 \%$, even though the proportion varied markedly in individual months. From October to March, and particularly 
from November to February, diffuse radiation is clearly predominant in comparison with direct radiation. The proportion is reversed only from April till September and particularly in June when the share of direct radiation is, on average, $53.5 \%$ of the sum of global solar radiation (Table 3).

Table 2. Percentage distribution of the sums of global solar (a), diffuse (b) and direct (c) radiation per months and seasons in Agrometeorological Station in Lipnik. Period 2008-2017

\begin{tabular}{ccccccccccccccccc}
\hline & I & II & III & IV & V & VI & VII & VIII & IX & X & XI & XII & III-V & VI-VIII & IX-XI & XII-II \\
\hline a & 1.8 & 3.4 & 7.1 & 11.5 & 15.0 & 15.7 & 15.6 & 12.9 & 9.0 & 4.8 & 2.0 & 1.3 & 33.6 & 44.2 & 15.8 & 6.4 \\
\hline b & 3.1 & 4.8 & 8.3 & 11.0 & 13.5 & 13.6 & 13.8 & 12.1 & 8.9 & 5.7 & 3.2 & 2.3 & 32.8 & 39.5 & 17.8 & 10.2 \\
\hline c & 0.5 & 1.8 & 5.9 & 12.0 & 16.5 & 17.9 & 17.6 & 13.8 & 9.2 & 3.9 & 0.7 & 0.2 & 34.5 & 49.3 & 13.8 & 2.5 \\
\hline
\end{tabular}
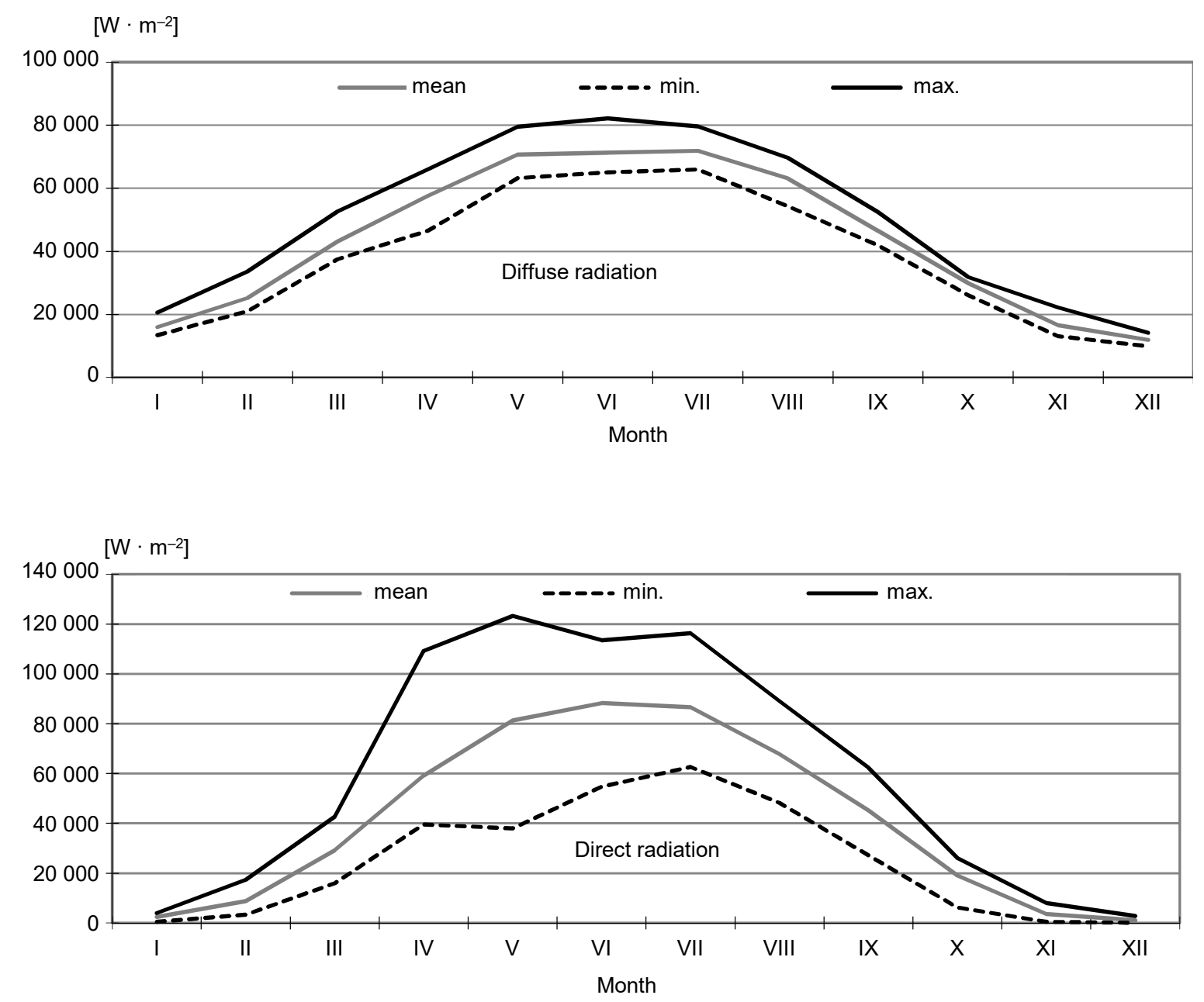

Fig. 3. The course of average, minimum and maximum monthly sums of diffuse and direct radiation in a year in Agrometeorological Station in Lipnik. Period $2008-2017$ 
Table 3. Percentage share of the monthly sums of diffuse (a) and direct (b) radiation in the monthly sums of global solar radiation in Agrometeorological Station in Lipnik. Period 2008-2017

\begin{tabular}{|c|c|c|c|c|c|c|c|c|c|c|c|c|c|}
\hline & 1 & II & III & IV & V & VI & VII & VIII & IX & $X$ & XI & XII & $I-X I I$ \\
\hline a & 86.7 & 74.0 & 59.7 & 49.3 & 46.5 & 44.7 & 45.3 & 48.2 & 50.7 & 61.2 & 82.5 & 91.6 & 51.5 \\
\hline b & 13.3 & 26.0 & 40.3 & 50.7 & 53.5 & 55.3 & 54.7 & 51.8 & 49.3 & 38.8 & 17.7 & 8.4 & 48.5 \\
\hline
\end{tabular}

According to Biszczuk-Jakubowska and Curyło (2010), most of the days in the period from November to January can exhibit daily solar radiation dose of less than $200 \mathrm{~J} \cdot \mathrm{m}^{-2}$, which puts us at risk of vitamin $D_{3}$ deficiency which can be prevented either through taking vitamin supplements or appropriate diet. The authors also claim that residents of Poland are particularly at risk of UV radiation deficiency.

In temperate latitudes in Poland, the biological action of UV-A occurs from $20^{\circ}$ of the height of the sun above the horizon, i.e. from the third decade of January, and UV-B from $30^{\circ}-$ from the first decade of March (Błażejczyk and Kunert 2011).

Fluctuations in the intensity of global solar radiation presented in Fig. 4 show a substantial variability of this climatic element on day to day basis. In the 24-hour period distribution of average sums of global solar radiation in a year, it is possible to distinguish a few days long periods of increased and decreased values of the said radiation, particularly in the warm halfyear - e.g. between 8 and 10 of April, 1 - 19 May, 26 - 31 August (Fig. 4).

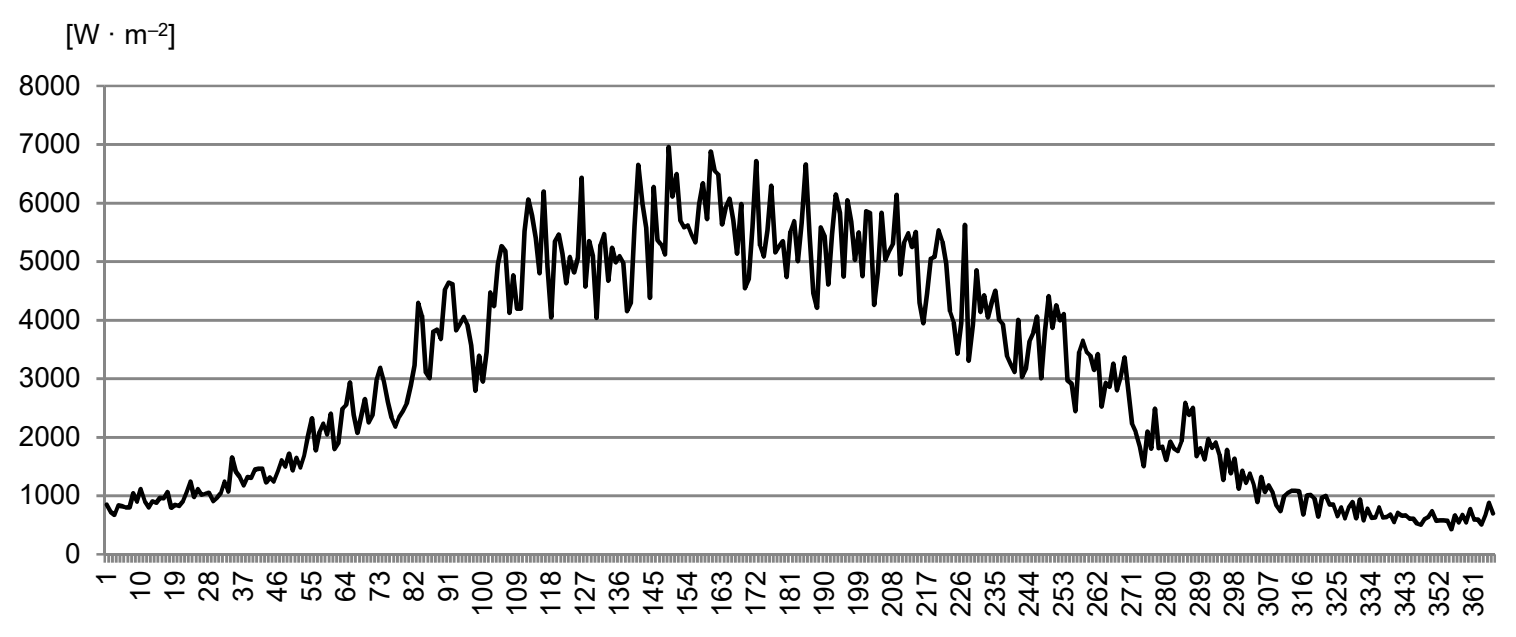

Days

Fig. 4. Distribution of average 24-hour period sums of global solar radiation in Agrometeorological Station in Lipnik. Period 2008-2017

Table 4 shows the hourly distribution of the amount of global solar and direct radiation for the selected sunny day, i.e. June 24, in a month of the highest radiation intensity in 2008. The highest intensity of global solar and direct radiation is recorded in the area of Lake Miedwie between 11 a.m. and 3 p.m. For these reasons doctors advise their patients to limit sun exposure and long-term sunbathing in the aforementioned hours, especially during the first days of heliotherapy after the winter period (Bielecka-Grzela et al. 2005; Huryń et al. 2006). Moreover, it is important to act with moderation and common sense when exposing oneself to solar radiation in the noon hours in summer. 
Table 4. Duration of skin erythema dose (SED) on a selected sunny day in minutes in 2008, Agrometeorological Station in Lipnik

\begin{tabular}{|c|c|c|c|c|c|c|}
\hline & \multirow{2}{*}{ Hour } & \multirow{2}{*}{$\begin{array}{c}\text { Global solar radiation } \\
{\left[\mathrm{W} \cdot \mathrm{m}^{-2}\right]}\end{array}$} & \multirow{2}{*}{$\begin{array}{l}\text { Direct radiation } \\
{\left[\mathrm{W} \cdot \mathrm{m}^{-2}\right]}\end{array}$} & \multicolumn{3}{|c|}{$\begin{array}{l}\text { Duration of skin erythema dose (SED) } \\
\text { [min] }\end{array}$} \\
\hline \multirow{13}{*}{ 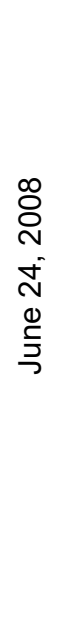 } & & & & blond & chestnut & dark \\
\hline & 08:00 & 323.9 & 270.9 & 93 & 103 & 111 \\
\hline & 09:00 & 452.0 & 343.3 & 73 & 81 & 87 \\
\hline & 10:00 & 551.3 & 390.8 & 64 & 71 & 77 \\
\hline & 11:00 & 677.8 & 514.2 & 49 & 54 & 58 \\
\hline & 12:00 & 858.5 & 762.6 & 33 & 37 & 39 \\
\hline & 13:00 & 858.5 & 762.6 & 33 & 37 & 39 \\
\hline & 14:00 & 846.8 & 737.5 & 34 & 38 & 41 \\
\hline & 15:00 & 796.6 & 653.5 & 38 & 43 & 46 \\
\hline & 16:00 & 775.1 & 677.1 & 37 & 41 & 44 \\
\hline & 17:00 & 625.4 & 531.2 & 47 & 53 & 57 \\
\hline & 18:00 & 451.3 & 381.8 & 66 & 73 & 79 \\
\hline & 19:00 & 335.0 & 265.2 & 95 & 105 & 113 \\
\hline
\end{tabular}

Knowing the amount of direct radiation in warm half-year, it is possible to determine the duration of skin erythema dose (SED) at various hours of a day, based on the stipulation by S. Tyczka (1975) that the average skin erythema dose (AED) during the first instance of heliotherapy after winter is $36 \mathrm{~min}$ for people with blond hair, $40 \mathrm{~min}$ - chestnut hair, and dark hair $-43 \mathrm{~min}$.

As is presented in Table 4 and Fig. 5, in the area of Lake Miedwie, an increase in intensity of direct radiation is accompanied by the shortening duration of the first safe tanning period for people with different skin complexion. For example on 24.06.2008, at the direct radiation value of $270,9 \mathrm{~W} \cdot \mathrm{m}^{-2}$ recorded at 8 a.m., the time of sunbathing to cause erythema for people with blond hair was 93 minutes, chestnut hair - 103, and dark hair - 111 minutes. However, at the intensity of $762,6 \mathrm{~W} \cdot \mathrm{m}^{-2}$ recorded at 12 , the duration of skin erythema dose was 33 minutes for people with blond hair, chestnut hair - 37, and dark hair - 39 minutes. However, in the afternoon the duration would increase again.

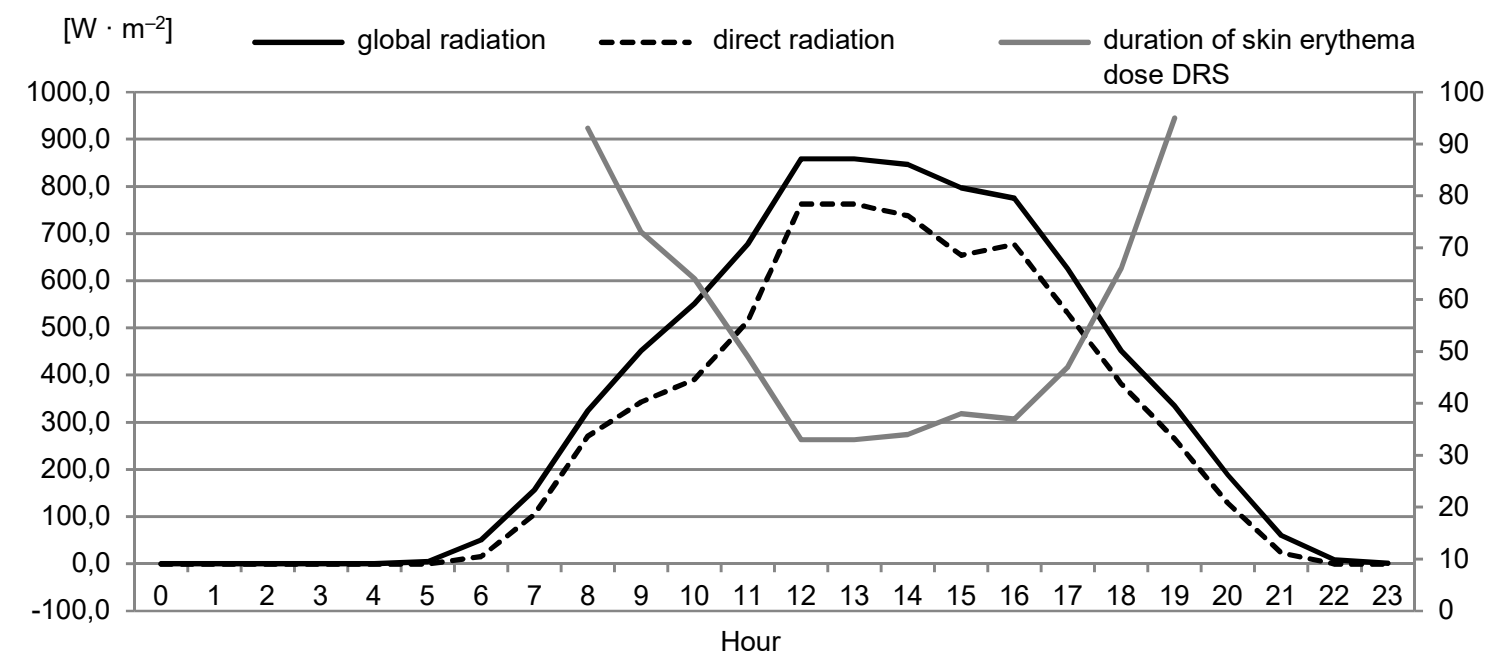

Fig. 5. The course of hourly values of global solar and direct radiation with duration of skin erythema dose (SED) for people with blond hair in a 24-hour period, 24.06.2008 in the area of Lake Miedwie 
High intensity of direct radiation occurring in the noon hours in the summer only confirms the recommendations of doctors to avoid long-term sun exposure between 11 a.m. and 2 p.m., especially by people with light complexion and during the first days of sunbathing after the winter period. Nonetheless, it is also important to sunbathe cautiously in the noon hours in summer. Exposing the skin without the protection of UV-filter to sun for 15-30 minutes a day, depending on the skin phototype, can facilitate vitamin D synthesis in the skin (Woźniacka et al. 2002; Bielecka-Grzela et al. 2005). Biodiversity of the area around Lake Miedwie favours going for a walk and cycling which may be an alternative to sunbathing during days of intense solar radiation, according to the stipulation that our mood reflects the atmosphere of a given place.

\section{RECAPITULATION}

The analysis of the amount of global solar, diffuse and direct radiation in the area of Lake Miedwie allows to formulate the following valid results and conclusions:

- In the area of Lake Miedwie, global solar radiation is marked by varied values of the coefficient of variation on an annual basis, i.e. from $8.5 \%$ in August to $21.5 \%$ in November.

- In June and July, solar radiation to ground is at an even level, however a substantial increase in direct radiation is observed after March 21 followed by a marked decrease after September 23.

- The sums of direct radiation in spring are more than twice as high as that recorded in autumn, and in summer the sums are 18 times greater than in winter.

- From October to March, diffuse radiation is predominant in comparison to direct radiation, which negatively affects the bioclimatic conditions.

- In the 24-hour period distribution of sums of global solar radiation in a year, there are a few days long periods of increased and decreased values of the said radiation.

- Starting from the last days of March to the last decade of August, average daily sums of global solar radiation are above $4000 \mathrm{~W} \cdot \mathrm{m}^{-2}$, and from mid-April to the first days of August above $5000 \mathrm{~W} \cdot \mathrm{m}^{-2}$.

- During periods of high intensity of solar radiation (more than $750 \mathrm{~W} \cdot \mathrm{m}^{-2}$ ), safe tanning time at first sun exposure is approximately 30-40 minutes, depending on skin complexion,

\section{REFERENCES}

Atlas zasobów i zagrożeń klimatycznych Pomorza. 2004. Red. C. Koźmiński, B. Michalska. Szczecin, AR, 65 .

Bielecka-Grzela S., Klimowicz A., Załuga E., Żejmo M. 2005. Ochrona skóry przed szkodliwym działaniem promieniowania ultra fioletowego [Protecting the skin against harmful UV radiation]. Ann. Acad. Med. Stett. 2(51), 2 33-37. [in Polish]

Biometeorologia turystyki i rekreacji. 1999. Red. J. Bogucki. Poznań, Wydaw. AWF. [in Polish]

Biszczuk-Jakubowska J., Curyło A. 2010. Słoneczne promieniowanie UV a zdrowie człowieka [Solar UV radiation and human heath]. Pr. Inst. Elektron. 244, 93-106. [in Polish]

Błażejczyk K., Kunert A. 2011. Bioklimatyczne uwarunkowania rekreacji i turystyki w Polsce. Warszawa, IGiPZ PAN, 366. [in Polish] 
Bryś K. 2013. Dynamika bilansu radiacyjnego murawy oraz powierzchni nieporośniętej [Dynamics of radiation balance of grassed and ungrassed areas]. Monogr. Uniw. Przyrod. Wroc. 162, 288. [in Polish]

Crove P.R. 1987. Problemy klimatologii ogólnej. Warszawa, PWN. [in Polish]

Huryń A., Bielecka-Grzela S., Klimowicz A. 2006. Zastosowanie fototerapii w dermatologii [Application phototheraphy in dermatology]. Ann. Acad. Med. Stett. 7, 52. [in Polish]

Jezioro Miedwie i Nizina Pyrzycka. 2007. Red. R.K. Borówka. Szczecin, Wyd. Oficyna In Plus. [in Polish]

Kędziora A. 1999. Podstawy agrometeorologii. Poznań, PWRiL. [in Polish]

Kozłowska-Szczęsna T., Krawczyk B., Kuchcik M. 2004. Wpływ środowiska atmosferycznego na zdrowie i samopoczucie człowieka. Warszawa, IGiPZ PAN. [in Polish]

Koźmiński C., Michalska B. 2000. Klimatyczna charakterystyka rejonu Stacji Agrometeorologicznej w Lipkach k. Stargardu. Szczecin, AR, 84. [in Polish]

Koźmiński C., Michalska B. 2005. Usłonecznienie rzeczywiste w Polsce [Real sunshine in Poland]. Monogr. Szczecin, AR, 110. [in Polish]

Koźmiński C., Mąkosza A., Michalska B. 2007. Bioklimatyczne warunki wypoczynku w rejonie jeziora Miedwie w półroczu ciepłym [Bioclimatic conditions for recreation at Lake Miedwie in the warm half-year]. Przegl. Nauk. 16(37)3, 3-13. [in Polish]

Koźmiński C., Michalska B., Czarnecka M. 2012. Klimat województwa zachodniopomorskiego. Szczecin, ZUT, 194. [in Polish]

Matuszko D. 2009. Wpływ zachmurzenia na usłonecznienie i całkowite promieniowanie słoneczne na przykładzie krakowskiej serii pomiarów. Kraków, Wydaw. UJ. [in Polish]

Tyczka S. 1975. Podstawy meteorologiczne zorganizowanej klimatoterapii w uzdrowiskach polskich [Meteorological grounds for organised climatotherapy in spas in Poland]. Probl. Uzdrow. 9(10), 97-98. [in Polish]

Woźniacka A., Lesiak A., Syga-Jędrzejewska A. 2002. Zastosowanie promieniowania ultrafioletowego w leczeniu dermatologicznym [Application of UV radiation in dermatlogical treatment]. Przegl. Lek. 59, $18-27$.

Wojewódzki Urząd Statystyczny w Szczecinie. 2016. Turystyka w województwie zachodniopomorskim w latach 2013-2015. Szczecin, Woj. Urz. Statyst. [in Polish]

\title{
OCENA PROMIENIOWANIA SŁONECZNEGO W REJONIE JEZIORA MIEDWIE NA POTRZEBY REKREACJI
}

\begin{abstract}
Streszczenie. Celem pracy jest ocena wielkości i zmienności sum promieniowania całkowitego, rozproszonego i bezpośredniego w rejonie jeziora Miedwie oraz wynikających z tego uwarunkowań rekreacyjnych. Wykorzystano godzinne i dobowe wyniki pomiarów wyżej wymienionych rodzajów promieniowania słonecznego ze Stacji Agrometeorologicznej w Lipniku k. Stargardu (z lat 2008-2017), mierzonych przyrządem Delta T BF3 Sunshine Sensors. Określono czasowy rozkład promieniowania całkowitego, rozproszonego i bezpośredniego, według godzin, dni, miesięcy, sezonów i roku, podając wartości średnie i ekstremalne oraz współczynnik zmienności (W\%). Obliczono procentowy udział sum wielkości promieniowania rozproszonego i bezpośredniego w sumach promieniowania całkowitego, a dla wybranego dnia podano czas bezpiecznego opalania dla blondynów, szatynów i brunetów, przebywających w ciepłym półroczu w rejonie jeziora Miedwie, na podstawie dawek rumieniowych skóry (DRS). Wyniki obliczeń przedstawiono w formie tabelarycznej i graficznej. Ważniejsze wnioski: duża czasowa zmienność i nierównomierność rozkładu różnych rodzajów promieniowania z miesiąca na miesiąc i z roku na rok, ponaddwukrotna przewaga promieniowania bezpośredniego wiosną, w odniesieniu do jesieni, i ponadosiemnastokrotna przewaga tego promieniowania latem, w odniesieniu do zimy, występowanie w dobowym rozkładzie promieniowania kilkudniowych okresów o jego zwiększonej i zmniejszonej sumie. W okresie od maja do sierpnia natężenie promieniowania bezpośredniego w godzinach okołopołudniowych w dni słoneczne może być uciążliwe, a przy dłuższym opalaniu nawet niebezpieczne dla zdrowia.
\end{abstract}

Słowa kluczowe: promieniowanie słoneczne, rodzaje, wielkość, zmienność, rozkład czasowy, uwarunkowania rekreacyjne. 